\title{
MULTILEVEL SEBAGAI ANALISA PENDAPATAN USAHA MIKRO, KECIL DAN MENENGAH (UMKM) DI PROVINSI ACEH
}

\author{
Wanda Sri Noviana ${ }^{1}$, Miftahuddin ${ }^{2 *}$, Eddy Gunawan ${ }^{3}$ \\ 1,2 Jurusan Statistika, Universitas Syiah Kuala, Banda Aceh 23111, Indonesia \\ ${ }^{3}$ Jurusan Ekonomi dan Pembangunan, Universitas Syiah Kuala, Banda Aceh 23111, Indonesia \\ *Penulis Korespondensi.Email: miftah@unsyiah.ac.id
}

\begin{abstract}
Abstrak
Penelitian pengaruh faktor kategori sektor UMKM dan daerah sering diabaikan, sehingga dalam hal ini regresi sederhana dapat ditingkatkan melalui pengklasifikasian kumpulan data serupa. Oleh karena itu, untuk meningkatkan pemahaman tentang faktor-faktor yang mempengaruhi pendapatan UMKM perlu dipertimbangkan dengan melihat hubungan dari kategori sektor UMKM dan kabupaten/kota (daerah) yang berbeda khususnya di Provinsi Aceh. Tujuan dari analisis regresi multilevel ini untuk membentuk model regresi tentang besarnya pendapatan UMKM di Provinsi Aceh dimana individu pemilik usaha level 1 dengan faktor jenis usahanya, banyaknya tenaga kerja dan besarnya modal, bersarang di sektor UMKM level 2, bersarang di kabupaten/kota level 3. Metode yang digunakan dalam pengolahan data adalah pemodelan multilevel dengan data yang digunakan yaitu data UMKM yang diperoleh dari Dinas Koperasi dan UMKM Aceh. Hasil penelitian menunjukkan bahwa jenis usaha pertambangan, pertanian dan peternakan memiliki pengaruh negatif yang signifikan 5\% terhadap pendapatan UMKM di Provinsi Aceh, sedangkan jenis usaha transportasi, modal dan tenaga kerja memiliki pengaruh positif signifikan 5\%. Ukuran kesesuaian model regresi 3-level diperoleh masing-masing deviance, AIC dan BIC adalah 22.571, 22.585 dan 22.636.
\end{abstract}

Kata Kunci: Regresi Berganda; Pemodelan Multilevel; Korelasi Interkelas; UMKM

\begin{abstract}
Studies the influence of the MSME sector and regional categorical factors is often overlooked, so in this case a simple regression can be improved through classifying similar data sets and being handled properly. Therefore, to increase understanding of the factors that affect the income of MSMEs, it must be considered by looking at the relationship between the categories of the MSME sector and different districts / cities (regions) especially in Aceh Province. One of the analysis models suitable for MSME data is multilevel regression analysis. The purpose of this multilevel regression analysis is to form a regression model on the amount of MSME income in Aceh Province where individual level 1 business owners with factors of type of business, number of workers and amount of capital, are nested in the level 2 MSME sector, nesting in level 3 districts I cities. The data used are UMKM data obtained from the Aceh Cooperative and UMKM Service. The data were processed and analysed using the R-Studio software. The results showed that the type of mining, agriculture and livestock businesses had a significant negative effect of $5 \%$ on the income of MSMEs in Aceh Province, while the types of transportation, capital and labor businesses had a significant positive effect of 5\%. The measure of suitability of the 3-level regression model obtained deviance, AIC and BIC, respectively, is 22,571, 22,585 and 22,636.
\end{abstract}

Keywords: Multiple Regression; Multilevel Modelling; Interclass Correlation; UMKM

\section{Pendahuluan}

Sektor riil yang akhir-akhir ini mendapat perhatian besar dari pemerintah pusat dan daerah maupun kalangan bisnis adalah sektor usaha mikro, kecil, dan menengah (UMKM). Beberapa studi mengenai UMKM yang telah dilakukan menunjukkan bahwa pada masa krisis, usaha skala kecil mempunyai ketahanan relatif lebih baik dibandingkan usaha besar. Selain berperan sebagai 
penyangga perekonomian nasional, UMKM berperan positif dalam membuka lapangan pekerjaan maupun mengatasi kemiskinan [1]. Menurut Muzammil [2] suatu realita perkembangan UMKM selalu beriringan dengan perkembangan ekonomi dengan dibuktikan oleh struktur ekonomi di Provinsi Aceh yang semakin didominasi oleh jumlah UMKM yang terus bertambah diseluruh wilayah. Disebutkan pula bahwa populasi UMKM di Provinsi Aceh bergerak dalam berbagai jenis dan kegiatan ekonomi seperti pertanian, peternakan, perikanan, industri, perdagangan baik di desa maupun di kota. Data pendapatan UMKM dalam bidang perekonomian mengandung struktur hirarki. Struktur hirarki dalam data pendapatan UMKM di Provinsi Aceh adalah individu UMKM yang tersarang dalam sektor UMKM dan sektor UMKM tersarang dalam Kabupaten/Kota di Provinsi Aceh.

Penelitian yang mengkaji faktor-faktor mempengaruhi pendapatan UMKM dilakukan oleh Artini [3] dengan hasil akhir variabel modal dan tenaga kerja memiliki pengaruh signifikan terhadap total pendapatan UMKM di Kabupaten Tabanan. Tiga hal dalam memajukan dan mengembangkan UMKM di Indonesia, (1) peningkatan profil; (2) penguraian masalah melalui solusi yang tepat, dan strategi pemberdayaan UMKM [4]. Besarnya jumlah UMKM sebagai penggerak ekonomi nasional, hal ini terlihat berdasarkan data Kementerian Koperasi, Usaha Keci, dan Menengah (KUKM) tahun 2018 terdapat jumlah UMKM 64,2 juta (99,99\%) dari jumlah pelaku usaha di Indonesia. Daya serap tenaga kerja UMKM adalah hampir dua kali lipat jumlah UMKM yaitu 117 juta pekerja (97\%) dari daya serap tenaga kerja dunia usaha. Sedangkan kontribusi UMKM terhadap perekonomian nasional berdasarkan Produk Domestik Bruto sebesar 61,1\%, dan 38,9\% oleh pelaku usaha besar berjumlah $5.55(0,01 \%)$ dari jumlah pelaku usaha.[5]. Untuk mendapatkan modal usaha, banyak cara dan strategi yang digunakan, diantaranya bagi UMKM industri kreatif kerajinan batik memberi jaminan gadai hak mereknya [6]. Selain modal usaha, model pemasaran produk, penggunaan digitalisasi menjadi penting pada masa tidak normal (masa pandemic covid-19), seperti fintech, media sosial, dan pemanfaatan literasi finansial syariah [7]. Selain itu Ismatullah [8] menunjukkan bahwa variabel modal dan tenaga kerja memiliki pengaruh positif terhadap tingkat pendapatan UMKM di Kota Surakarta. Oleh karena itu, dalam penentuan level terendah (level 1) digunakan variabel penjelas berupa jenis usaha, tenaga kerja dan modal untuk melihat pengaruh terhadap total pendapatan individu UMKM di Provinsi Aceh.

Pada level 2 (sektor UMKM) dan level 3 (kabupaten/kota) tidak ada variabel penjelas yang diukur. Analisis yang dapat dilakukan untuk bentuk seperti ini yaitu analisis regresi multilevel. Menurut Harlan [9] analisis data menggunakan pemodelan multilevel yang tersusun dari beberapa grup pada level yang lebih tinggi tanpa pengukuran variabel penjelas pada level tersebut dapat diselesaikan menggunakan analisis regresi multilevel. Beberapa penelitian yang menggunakan regresi multilevel [10] pada data konsumsi energi listrik di Provinsi Aceh menggunakan model regresi 3-level. Model yang sama untuk penelitian faktor-faktor yang mempengaruhi pendidikan anak di Kabupaten Semarang berdasarkan lamanya pendidikan bapak dan ibunya [11] dan pemilihan model multilevel terbaiknya [12].

Berdasarkan uraian di atas, pada penelitian ini dibahas mengenai pemodelan regresi multilevel pada data pendapatan UMKM di Provinsi Aceh dengan tiga tingkatan (3-level) dari Dinas Koperasi dan UMKM Aceh. Melalui penelitian ini dijelaskan dalam penentuan model terbaik untuk data UMKM yang memiliki struktur hirarki dan menjelaskan adanya keragaman atau variansi yang mempengaruhi respon pada setiap level dalam model tersebut. Uraian per wilayah kabupaten/kota di Aceh juga menarik untuk diteliti.

\section{Metode Penelitian}

Data yang digunakan dalam penelitian ini berupa data sekunder yang diperoleh dari Dinas Koperasi dan UMKM Aceh dan dianalisis menggunakan software R-Studio untuk perolehan model dan uji signifikansi data pendapatan individu UMKM. Prosedur penelitian yang dilakukan pada penelitian ini adalah sebagai berikut:

1. Analisis deskriptif pada data pendapatan UMKM di Provinsi Aceh yaitu ringkasan statistik dan 
visualisasi data.

2. Membuat regresi berganda pada level 1 tanpa melibatkan efek sektor UMKM dan kabupaten/kota dengan langkah-langkah sebagai berikut:

a. Pendapatan sebagai variabel respon $(y)$ dan tiga variabel penjelas $(x)$ yaitu jenis usaha $\left(x_{1}\right)$, tenaga kerja $\left(x_{2}\right)$ dan modal $\left(x_{3}\right)$ dengan persamaan sebagai berikut:

$$
y=\beta_{0}+\beta_{1} x_{1}+\beta_{2} x_{2}+\beta_{3} x_{3}+\varepsilon
$$

b. Melakukan pemeriksaan multikolinearitas pada regresi berganda yang dibentuk.

3. Melakukan pengujian terhadap struktur tersarang dari level 3 dan level 2 menggunakan perbedaan deviance.

$$
\Delta D=D_{1}-D_{2}
$$

Dimana $D_{1}$ adalah deviance pada model komponen varian level 3 dan $D_{2}$ adalah deviance pada model komponen varian level 2.

4. Membangun model multilevel dengan memperhatikan pengaruh sektor UMKM dan kabupaten/kota.

Model Level 1:

$$
y_{i j k}=\beta_{0 j k}+\beta_{1 j k} x_{1 j k}+\beta_{2 j k} x_{2 j k}+\beta_{3 j k} x_{3 j k}+\varepsilon_{i j k}
$$

Model Level 2:

$$
\beta_{0 j k}=\gamma_{00 k}+u_{i j k}
$$

Model Level 3:

$$
\gamma_{00 k}=\delta_{000}+v_{0 k}
$$

dimana:

$\beta_{1 j k}$ : efek tetap (fixed effects) variabel jenis usaha pada klasifikasi UMKM ke-j dan kabupaten/kota di Provinsi Aceh ke- $k$

$\beta_{2 j k}$ : efek tetap (fixed effects) variabel tenaga kerja pada klasifikasi UMKM ke-j dan kabupaten/kota di Provinsi Aceh ke- $k$

$\beta_{3 j k}$ : efek tetap (fixed effects) variabel modal pada klasifikasi UMKM ke-j dan kabupaten/kota di Provinsi Aceh ke- $k$

$y_{i j k}:$ nilai respon pada observasi ke-i, sektor UMKM ke-j, dan kabupaten/kota di Provinsi Aceh ke- $k$

$\beta_{0 j k} \quad$ : intersep acak pada klasifikasi UMKM ke-j dan kabupaten/kota di Provinsi Aceh ke- $k$

$\gamma_{00 k} \quad$ : intersep acak pada kabupaten/kota di Provinsi Aceh ke- $k$

$\varepsilon, u, v:$ residuals secara berturut-turut pada level 1, level 2 dan level 3

5. Membandingkan model multilevel dengan menggunakan nilai AIC, BIC dan deviance untuk mendapatkan model optimal.

6. Menganalisa hasil dan menarik kesimpulan.

\section{Hasil dan Pembahasan}

\subsection{Analisis Deskriptif}

\subsubsection{Ringkasan Statistik}

Ringkasan statistik merupakan hasil dari sejumlah ringkasan data berupa tabel yang berisi informasi jumlah observasi yang kosong (missing value), mean, median, simpangan baku dan lainlain. Ringkasan statistik dari data UMKM di Provinsi Aceh disajikan pada Tabel 1. 
Tabel 1. Ringkasan statistik data UMKM di Provinsi Aceh

\begin{tabular}{cccc}
\hline Ringkasan Statistik & Tenaga Kerja (org) & Modal $(\mathrm{Rp})$ & Pendapatan $(\mathrm{Rp})$ \\
\hline Minimum & 1 & 100.000 & 100.000 \\
Kuartil 1 & 2 & 270.000 & 150.000 \\
Median & 2 & 420.000 & 200.000 \\
Mean & 3 & 900.786 & 352.000 \\
Modus & 2 & 300.000 & 200.000 \\
Kuartil 3 & 4 & 832.500 & 350.000 \\
Maksimum & 29 & 48.840 .000 & 33.000 .000 \\
Interkuartil & 2 & 562.500 & 200.000 \\
Range & 28 & 48.740 .000 & 32.900 .000 \\
Standar Deviasi & 3 & 2.248 .709 & 840.789 \\
Skewness & 0,333 & 0,267 & 0,181 \\
\hline
\end{tabular}

Pendapatan UMKM paling rendah di Provinsi Aceh sebesar Rp. 100.000, rata-rata pendapatan sebesar Rp. 352.000, dan pendapatan terbesar yang diperoleh sebesar Rp. 33.000.000. Modal UMKM di Provinsi Aceh paling rendah sebesar Rp. 100.000, rata-rata modal usaha sebesar Rp. 900.786, dan modal terbesar yang digunakan sebesar Rp. 48.840.000. Jumlah tenaga kerja pada suatu UMKM di Provinsi Aceh terkecil sebesar 1 orang, rata-rata jumlah tenaga kerja sebesar 3 orang, dan jumlah tenaga kerja tertinggi sebesar 29 orang.

\subsubsection{Visualisasi Data}

Visualisasi data merupakan tampilan grafis dari sebuah informasi dan data yang akan memudahkan dalam memahami pola dalam suatu data dan memungkinkan menarik sebuah keputusan yang disajikan secara visual. Visualisasi data UMKM di Provinsi Aceh ditampilkan pada Gambar 1.

Pendapatan UMKM di Provinsi Aceh

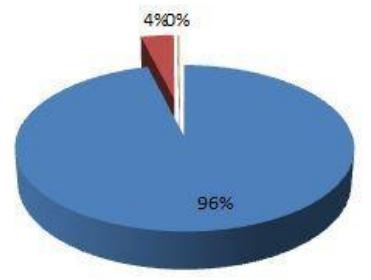

M $<$ Rp. 1.000 .000

= Rp. $1.000 .000-R p$

10.000 .000

$=\mathrm{Rp} .11 .000 .000-\mathrm{Rp}$

50.000 .000

\section{Modal UMKM di Provinsi Aceh}

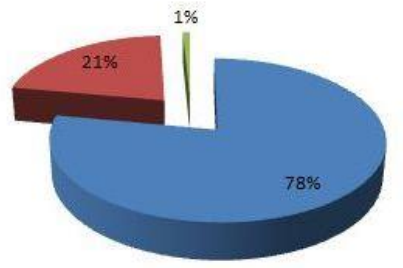

Gambar 1. Pie chart data UMKM Provinsi Aceh

Informasi yang dapat dilihat pada Gambar 1 yaitu 96\% individu pelaku usaha minim pendapatan hanya sebesar kecil dari Rp. 1.000.000 hal tersebut dapat terjadi karena modal yang digunakan individu pelaku usaha juga minim yaitu sebesar $78 \%$ individu pelaku usaha memiliki modal kecil dari Rp. 1.000.000. Modal sebagai komponen penting pada awal suatu usaha dalam melakukan kegiatan bisnis ini sangat penting. Semakin besar jumlah modal yang digunakan maka suatu usaha tersebut akan memiliki muatan yang besar pula dalam usaha memproduksi dan mendistribusi permintaan pasar sehingga akan menghasilkan pendapatan dan keuntungan yang besar pula [13].

\subsection{Analisis Regresi Multilevel}

\subsubsection{Pemodelan Data Pendapatan UMKM}

Data pada level 1 dianalisis menggunakan regeresi berganda. Variabel penjelas pada pemodelan ini terdiri dari jenis usaha, tenaga kerja (orang), dan modal (rupiah). Sedangkan variabel responnya adalah pendapatan (rupiah). Analisis ini merupakan awal dari analisis regresi multilevel pada level 1 untuk mengetahui hubungan antar variabel respon dan variabel penjelas. Model ini 
menjadi pembanding bagi model-model lain [12]. Data dalam penelitian memiliki satuan ukur yang berbeda sehingga data asli harus distandarisasi dalam bentuk z-score sebelum dianalisis. Analisis regresi berganda disajikan pada Tabel 2 .

Tabel 2. Analisis regresi berganda (Level 1)

\begin{tabular}{cc}
\hline & Estimasi \\
\hline Intercept & $-1,365 \mathrm{e}-14$ \\
$x_{1}($ Jenis Usaha $)$ & $1,827 \mathrm{e}-02$ \\
$x_{2}$ (Tenaga Kerja) & $6,104 \mathrm{e}-02$ \\
$x_{3}$ (Modal) & $6,686 \mathrm{e}-01$ \\
\hline
\end{tabular}

Pada analisis regresi berganda untuk data level 1 akan dilakukan pemeriksaan multikolinearitas dikarenakan hal terpenting dalam pemodelan multilevel adalah tidak terdapat korelasi atau hubungan antar individu dalam sampel untuk variabel penjelas yang diikutkan dalam analisis regresi multilevel [14]. Dimungkinkan untul menyelidiki hal tersebut dengan cara melihat nilai VIF.

Hipotesis uji multikolinearitas adalah sebagai berikut:

$\mathrm{H}_{0} \quad$ : Terdapat multikolinearitas antar variabel penjelas (VIF $>10$ )

$\mathrm{H}_{0} \quad$ : Tidak terdapat multikolinearitas antar variabel penjelas (VIF $<10$ )

Nilai Nilai variance inflation factor (VIF) yang digunakan pada penelitian ini disajikan pada Tabel 3 .

Tabel 3. Nilai variance inflation factor (VIF)

\begin{tabular}{ccc}
\hline Variabel Penjelas & df & VIF \\
\hline Jenis Usaha $\left(x_{1}\right)$ & 6 & 1,001 \\
Tenaga Kerja $\left(x_{2}\right)$ & 1 & 1,011 \\
Modal $\left(x_{3}\right)$ & 1 & 1,014 \\
\hline
\end{tabular}

Berdasarkan Tabel 3 diketahui bahwa nilai dari VIF untuk masing-masing variabel penjelas pada level 1 memiliki nilai yang lebih kecil dari 10 sehingga keputusannya adalah menolak $\mathrm{H}_{0}$. Artinya, tidak terdapat multikolinearitas antara variabel penjelas pada level 1 atau dengan kata lain tidak terdapat hubungan (korelasi) antar variabel jenis usaha, tenaga kerja dan modal.

\subsubsection{Penjelasan Struktur Tersarang Model Multilevel}

Analisis data dengan menggunakan analisis regresi multilevel selanjutnya adalah membuat model tanpa melibatkan peubah penjelas. Model ini dapat disebut sebagai model komponen ragam (Variance Component Model). Model ini biasanya digunakan untuk melihat ada atau tidaknya pengaruh dari struktur pada model multilevel (tersarang) dari data tersebut, selain itu juga dapat ditentukan besarnya proporsi keragaman dalam level yang lebih tinggi [15]. Data pada Tabel 4 berikut merupakan nilai dari komponen variansi pada masing-masing level untuk model multilevel (3-level) tanpa variabel penjelas data usaha mikro, kecil, dan menengah di Provinsi Aceh.

Tabel 4. Nilai estimasi variansi pada model multilevel 3-level tanpa variabel penjelas

\begin{tabular}{cc}
\hline Parameter & Estimasi \\
\hline$\sigma_{v 0}^{2}($ level 3) & 1,248 \\
$\sigma_{u 0}^{2}($ level 2) & 0,591 \\
$\sigma_{e 0}^{2}($ level 1) & 0,918 \\
\hline
\end{tabular}

Berdasarkan Tabel 4 terlihat bahwa nilai komponen ragam pada level 3 lebih besar dibandingkan dengan nilai komponen ragam pada level 2 dan level 1 . Hal ini menunjukkan bahwasannya terdapat keragaman dalam kabupaten/kota atau dapat juga dikatakan bahwasannya 
antara kabupaten/kota tidak homogen. Selanjutnya, untuk mengetahui secara statistika maka akan dilakukan pengujian struktur multilevel menggunakan korelasi intra class. Berdasarkan nilai estimasi parameter variansi pada Tabel 4 dapat diperoleh nilai koefisien korelasi intra class sebagai berikut.

$$
\begin{gathered}
\rho_{\text {sektor } U M K M}=\frac{1,248+0,591}{1,248+0,591+0,918}=0,667 \\
\rho_{\text {Kabupaten } / \text { kota }}=\frac{1,248}{1,248+0,591+0,918}=0,453
\end{gathered}
$$

Apabila nilai korelasi intra class di atas 0,05 atau sebesar 5\%, maka hal ini menunjukkan bahwa varians antar kelompok lebih besar daripada yang diharapkan dan mengimplikasikan bahwa penyarangan pada kelompok-kelompok tertentu memiliki pengaruh atau efek pada respon yang diberikan oleh individu-individu di dalamnya sehingga analisis regresi multilevel diperlukan [16]. Berdasarkan perhitungan statistik di atas memiliki arti bahwa proporsi variansi pada level sektor UMKM sebesar 66,7\% dan proporsi variansi pada level kabupaten/kota sebesar 45,3\%. Selain itu dapat diketahui pula bahwa korelasi antar observasi dalam satu kelompok sektor UMKM sebesar 0,667 dan dalam kabupaten/kota sebesar 0,453.

Berdasarkan nilai tersebut dinyatakan bahwa korelasi antar individu dalam setiap kabupaten/kota di Provinsi Aceh cukup besar. Hal ini menunjukkan bahwasannya terdapat perbedaan antara level 2 yaitu sektor UMKM dan level 3 yaitu kabupaten/kota di Provinsi Aceh terhadap data pendapatan usaha di Provinsi Aceh. Hal tersebut juga dapat dibuktikan dengan perbandingan nilai deviance. Nilai deviance pada model 3-level dan model 2-level data usaha mikro, kecil, dan menengah dapat dilihat pada Tabel 5.

Tabel 5. Nilai deviance pada model 3-level dan model 2-level tanpa variabel penjelas

\begin{tabular}{cccccc}
\hline Model & Parameter & Deviance & $\Delta D$ & Db & $p$-value \\
\hline 2-level & 3 & 29.562 & & & \\
3-level & 4 & 29.040 & 524,36 & 1 & $<2,2 \mathrm{e}-16$ \\
\hline
\end{tabular}

Berdasarkan tabel 5 dapat diketahui bahwa nilai deviance model 3-level lebih kecil dibandingkan dengan nilai deviance model 2-level. Selain itu juga terlihat bahwa terdapat perbedaan pada model 2-level dengan 3-level secara nyata pada taraf 5\%, yang berarti terdapat perbedaan yang nyata antara model regeri 2-level dan 3-level. Hal ini menunjukkan bahwa variansi dalam kabupaten/kota berpengaruh terhadap pendapatan usaha mikro, kecil dan menengah di Provinsi Aceh. Sehingga dapat dikatakan model multilevel 3-level merupakan model yang sesuai pada data usaha mikro, kecil dan menengah di Provinsi Aceh.

\subsubsection{Model Multilevel}

Pemodelan selanjutnya pada analisis regresi multilevel ini dilakukan untuk mengetahui pemodelan data UMKM di Provinsi Aceh dengan adanya pengaruh dari variansi level 2 (sektor UMKM) dan level 3 (kabupaten/kota). Berdasarkan pengujian struktur tersarang yang telah dilakukan sebelumnya, model multilevel yang dibentuk adalah model multilevel 3-level. Variabel pada level 3 adalah kabupaten/kota dan variabel pada level 2 adalah sektor UMKM. Hasil estimasi parameter untuk model multilevel 3-level yang diperoleh dapat dilihat pada Tabel 6.

Statistik uji yang digunakan adalah nilai $|t|$ dengan tingkat signifikansi 5\% dengan daerah penolakan apabila $|t|>t_{\frac{\alpha}{2} ; n-k-1}$ maka $\mathrm{H}_{0}$ ditolak. Pada penelitian ini besarnya nilai derajat bebas yaitu lebih besar dari 20. Apabila nilai derajat bebas adalah 20 atau lebih dengan tingkat signifikan $\alpha(0,05)$, maka $\mathrm{H}_{0}$ dapat ditolak jika nilai $|t|$ melebihi 2 dalam nilai absolut [17]. Sesuai dengan pernyataan tersebut terdapat beberapa variabel bebas yang nilai $|t|$ melebihi 2 yaitu jenis usaha 
pertambangan, pertanian, peternakan dan transportasi, serta faktor tenaga kerja dan modal yang berarti memiliki pengaruh secara signifikan terhadap pendapatan UMKM di Provinsi Aceh.

Tabel 6. Uji signifikansi parameter model multilevel 3-level

\begin{tabular}{ccc}
\hline & Estimasi & $t$-value \\
\hline Intercept & 0,333 & 1,085 \\
$x_{1}$ (Perdagangan) & 0,016 & 0,785 \\
$x_{1}$ (Perikanan) & $-0,069$ & $-0,914$ \\
$x_{1}$ (Pertambangan) & $-0,174$ & $\mathbf{- 3 , 0 4 9}$ \\
$x_{1}$ (Pertanian) & $-0,111$ & $\mathbf{- 2 , 1 7 5}$ \\
$x_{1}$ (Peternakan) & $-0,297$ & $\mathbf{- 6 , 1 0 1}$ \\
$x_{1}$ (Transportasi) & 0,198 & $\mathbf{4 , 6 1 0}$ \\
$x_{2}$ (Tenaga Kerja) & 0,076 & $\mathbf{1 0 , 0 0 0}$ \\
$x_{3}$ (Modal) & 0,675 & $\mathbf{9 2 , 6 0 2}$ \\
\hline
\end{tabular}

Keterangan: signifikansi pada $\alpha=0,05$ dengan ditandai penulisan bold pada $|t|$

Merujuk pada Tabel 6 di atas juga terlihat bahwa variabel tenaga kerja dan modal memiliki efek positif terhadap pendapatan usaha mikro, kecil, dan menengah di Provinsi Aceh. Artinya semakin tinggi jumlah tenaga kerja dan modal maka pendapatan usaha mikro, kecil, dan menengah di Provinsi Aceh juga akan semakin tinggi.

\subsubsection{Kecocokan Model}

Analisis kecocokan model dalam analisis regresi multilevel ini dilakukan untuk mengetahui seberapa kesesuaian model yang telah dibentuk. Perbandingan nilai yang digunakan adalah nilai AIC, BIC dan deviance. Nilai AIC, BIC dan deviance yang kecil dan menandakan suatu model yang dibentuk cocok atau sesuai. Pada penelitian ini dilakukan perbandingan nilai AIC, BIC dan deviance pada model level 1, model level 2 (tanpa variabel penjelas), model level 3 (tanpa variabel penjelas) dan regresi 3-level yang telah dilakukan pada data UMKM di Provinsi Aceh. Nilai yang digunakan untuk melihat perbandingan kecocokan model disajikan pada Tabel 7.

Tabel 7. Ukuran kesesuaian model

\begin{tabular}{lccc}
\hline \multicolumn{1}{c}{ Model } & Deviance & AIC & BIC \\
\hline $\begin{array}{c}\text { Model Level 1 } \\
\quad \text { (regresi berganda) }\end{array}$ & 23.979 & 24.054 & 24.090 \\
$\begin{array}{c}\text { Model Level 2 } \\
\quad \text { (tanpa variabel penjelas) } \\
\begin{array}{c}\text { Model Level 3 } \\
\quad \text { (tanpa variabel penjelas) }\end{array}\end{array}$ & 29.556 & 29.562 & 29.584 \\
$\begin{array}{c}\text { Model Regresi 3-level } \\
\text { (dengan variabel penjelas) }\end{array}$ & 29.032 & 29.040 & 29.069 \\
\hline
\end{tabular}

Berdasarkan Tabel 7 diketahui bahwa nilai AIC, BIC dan deviance dari model regresi multilevel yaitu model 3-level dengan variabel penjelas lebih kecil dibandingkan model lainnya yang telah terbentuk yang berarti bahwasannya model 3-level dengan variabel penjelas yang digunakan pada data pendapatan UMKM di Provinsi Aceh lebih baik dibandingkan dengan model lainnya.

\section{Kesimpulan}

Pada analisa data pendapatan UMKM dengan menggunakan model regresi multilevel (3level) menunjukkan bahwa jenis usaha pertambangan, pertanian, peternakan dan transportasi berpengaruh secara signifikan terhadap pendapatan UMKM di Provinsi Aceh. Selain itu ditambah faktor modal dan tenaga kerja juga berpengaruh secara signifikan sebesar 5\% terhadap pendapatan 
UMKM. Melalui model regresi 3-level diperoleh ukuran kesesuaian model masing-masing deviance, AIC dan BIC adalah 22.571, 22.585 dan 22.636.

\section{Referensi}

[1] Y. Yuliana, A. Hamzah, M. N. Syechalad, "Analisis Faktor-Faktor yang Mempengaruhi Permintaan Kredit Usaha Mikro Kecil dan Menengah Pada Bank Umum di Kota Banda Aceh," Jurnal Ilmu Ekonomi Pascasarjana Universitas Syiah Kuala, vol. 3, no. 1, pp. 17-26, 2015.

[2] M. Muzammil, "Faktor-Faktor yang Mempengaruhi Permintaan Kredit Usaha Mikro Kecil Menengah (UMKM) di Provinsi Aceh," Univeristas Teuku Umar, 2016.

[3] N. R. Artini, "Analisis Faktor-Faktor yang Mempengaruhi Pendapatan UMKM di Kabupaten Tabanan," Ganec Swara, vol. 13, no. 1, pp. 71-77, 2019.

[4] I. Y. Niode, "Sektor UMKM di Indonesia: Profil, Masalah, dan Strategi Pemberdayaan," Jurnal Kajian Ekonomi dan Bisnis OIKOS-NOMOS, Vol 2, No1, pp. 1-10, 2009.

[5] E. U. P. Nainggolan, "UMKM Bangkit, Ekonomi Indonesia Terungkit," Direktorat Jenderal Kekayaan Negara $\quad$ (DJKN), $2020 . \quad$ [Online]. Available: https://www.djkn.kemenkeu.go.id/artikel/baca/13317/UMKM-Bangkit-Ekonomi-IndonesiaTerungkit.html

[6] M. R. Hakim dan N. Kholidah, "Hak Merek sebagai Jaminan Gadai untuk Permodalan UMKM Industri Kreatif Kerajinan Batik," Pena Justisia: Media Komunikasi dan Kajian Hukum, Vol. 18, No. 2, pp.79-87, 2019.

[7] B. Arianto, "Pengembangan UMKM Digital di Masa Pandemi Covid-19," ATRABIS: Jurnal Administrasi Bisnis, Vol. 6, No. 2, pp. 163-171, 2020.

[8] R. G. Ismatullah, “Analisis Faktor-Faktor yang Mempengaruhi Tingkat Pendapatan Usaha Mikro, Kecil dan Menengah (UMKM) Kota Surakarta”, Universitas Sebelas Maret, 2014.

[9] J. Harlan, Analisis Multilevel, Jakarta: Penerbit Gunadarma, 2016.

[10] J. Fitri, "Pemodelan Konsumsi Energi Listrik di Provinsi Aceh Menggunakan Regresi Multilevel," Universitas Syiah Kuala, 2018.

[11] A. D. Paramitha, S. Suparti, dan T. Wuryandari, "Pemodelan Regresi 3-level dengan Metode Iterative Generalized Least Square (Studi Kasus: Lamanya pendidikan Anak di Kabupaten Semarang)," Jurnal Gaussian, Vol. 5, No. 1, pp. 21-30, 2016.

[12] B. Tantular, A. Aunuddin, dan H. Wijayanto, "Pemilihan Model Regresi Linier Multilevel Terbaik," Forum Statistika dan Komputasi, Vol. 14, No.2, pp. 1-7, 2009.

[13] T. Nurrahman dan F. Fikriah. "Analisis Usaha Mikro Kecil dan Menengah (UMKM) Sektor Perdagangan di Kota Banda Aceh," Jurnal Ilmiah Mahasiswa (JIM), vol. 2, no. 2, pp. 320328, 2017.

[14] W. H., Finch dan J. E. Bolin, Multilevel Modeling Using R, USA: CRC Press, 2017.

[15] B. T. West, K. B. Welch, and A. Galecki, Linear Mixed Models: A Practical Guide Using Statistical Software, USA: Chapman \& Hall/CRC, 2006.

[16] J. S. Sorra and N. Dyer, "Multilevel Psychometric Properties Of The AHRQ Hospital Survey On Patient Safety Culture," BMC Health Services Research, vol. 10, no. 199, pp. 1472-6932, 2010.

[17] N. D. Gujariati and C. D. Porter, Basic Econometrics, USA: Douglas Rainer, 2013. 